\title{
CONSUMER AND RETAILER PERCEPTIONS OF MARKET TRANSACTIONS AND THE COMPLAINING CONSUMER
}

\author{
G.G. ROUSSEAU \\ Department of Industrial and Organizational Psychology \\ University of Port Elizabeth
}

\begin{abstract}
The purpose of the study is to compare consumers' and retailers' perceptions of actions taken in particular types of buying situations. Hypotheses relating to differences existing between the perceptions of consumers and retailers of actions taken in the buying situation are proposed and empirically tested using data from a systematic random sample of 150 consumers and 47 retailers in the Port Elizabeth metropolitan area. Complaints about products recently bought by subjects in the sample were also analysed as part of the study. Results imply that perceptual differences occurred in five of the fourteen situations portrayed, indicating possible causes of consumer frustration. Complaints analysed through the survey identified inadequate after-sales service, defective or malfunctioning products, and perishable food items as main sources of dissatisfaction.
\end{abstract}

\section{OPSOMMING}

Die doel van hierdie studie is om verbruikers en kleinhandelaars se waarnemings van optrede in spesifieke koopsituasies te vergelyk. ' $n$ Hipotese dat verskille wel bestaan tussen die waarnemings van verbruikers en kleinhandelaars ten opsigte van optrede binne die koopsituasie, word gestel en empiries getoets. Data is verkry d.m.v. 'n sistematiese ewekansige steekproef met 150 verbruikers en 47 kleinhandelaars in die Port Elizabeth metropolitaanse gebied. Klagtes oor produkte onlangs aangekoop deur proefpersone in die steekproef is verder ontleed as deel van die studie. Resultate impliseer dat waarnemingsverskille voorkom in vyf van die veertien situasies uitgebeeld wat moontlike oorsake van frustrasies aandui. Klagtes ontleed deur die opname het ontoereikende na-verkope diens, foutiewe produkte en bederfbare voedselitems as hoofbronne van ontevredenheid geidentifiseer.

An important interaction between consumers and retailers occurs during and after the purchase of goods, ideally resulting in the use of and satisfaction with the product by the consumer. The attainment of this satisfaction is often hindered by the cumulative frustrations associated with transactions that do not conform to expectations (Dornoff \& Tankersley, 1982).

Dissatisfaction is greatest when the product does not perform its basic functions. There are however, a number of situations where a product may cause dissatisfaction because people do not always agree about expected standards of performance. Businessmen and consumers often have different perceptions regarding performance expectations (Day, 1982). Consumers may feel that the quality of products is deteriorating, while businessmen attribute dissatisfaction to unrealistically high performance expectations. Manufacturers and retailers suggest that advertising, which proclaims a flow of continuously improved products, is partly responsible for this situation.

The issue of consumer dissatisfaction is further complicated by the fact that companies which have kept a register of complaints received, conclude that large discrepancies often excist between what they and their clients perceive to be legitimate complaints (Hill, 1982). Resnik and Harmon (1983) examined manager and consumer perceptions of appropriate responses to complaint letters. Consumers in the study were more likely than managers to view complaints as legitimate. This finding was particularly true in situations where there seemed to be no obvious solutions to complaints.

Requests for reprints should be addressed to G.G. Rousseau, Department of Industrial and Organizational Psychology, University of Port Elizabeth, Port Elizabeth, 6000 .
Many firms have not worried about the potential negative effects of consumer dissatisfaction because they believe few consumers are dissatisfied with their products. Managers tend to use complaint rates as indicators of dissatisfaction and assume that if complaint rates are low, overall dissatisfaction is low (Richins, 1983). A review of consumer complaints only, however, presents a distorted and incomplete picture as many dissatisfied customers do not bother to complain. In a recent survey undertaken to examine consumer satisfaction with major household appliances, few respondents who had recorded dissatisfaction had made any complaints (Rousseau, 1985; 1986).

Apart from making a complaint to the seller, consumer reactions to dissatisfaction include switching brands or store and telling others about the unsatisfactory product or retailer (Richins, 1983). It would therefore be very misleading for most companies to rely solely on complaint letters as an indication of their product's performance. Consumers who tend to complain are likely to be people who have time on their hands and who are highly articulate and educated. They therefore come from the upper socio-economic groups. These people also tend to be more critical, they have higher standards and less tolerance for shortcomings due to problems in the past (Day, 1982). Loyalty towards the organization, the ability to detect quality differences in products, stress levels, and the perceptions of the costs and benefits to be derived from complaining will also determine willingness to give negative responses (Andreason 1984, 1985).

Regardless of the number of dissatisfied consumers who actually complain about products, one can assume that most retailers would be interested in preventing transactions which cause consumer frustration. Misunderstandings between retailers and consumers, often caused by perceptual differences in priorities set by both parties (i.e. short-term profit maximiza- 
tion versus maximum utility or value-for-money) can best be avoided by learning more about the dynamics involved in purchase transactions.

The purpose of this study is to compare consumers' and retailers' perceptions of actions taken in particular types of purchase transactions. The study was specifically designed to test the following hypothesis: differences exist between the perceptions by retailers and consumers of actions taken in market transactions. A further objective of the study was to analyse complaints of respondents in the sample who had indicated dissatisfaction with a recently-bought product.

\section{METHOD}

A sample of 150 consumers participated after 155 had initially been selected using a systematic random sample from the telephone directory of the Port Elizabeth metropolitan area. After a random start every tenth name was selected. Names listed from the Black and Coloured townships were excluded owing to the current unrest situation which made visits to these areas unsafe. Questionnaires were personally administered at home after respondents agreed over the telephone to participate in the study.

Three types of retail establishments were chosen to be sampled: department stores, speciality stores, and chain food outlets. These types of establishments represent business concerns referred to most frequently in letters of complaint received from consumers by the Consumer Association of Port Elizabeth. A systematic random sample was selected from the yellow pages in the telephone directory of the Port Elizabeth metropolitan area. Stores which could not be classified into one of the three types sampled, were excluded. Each retailer was contacted in person by the interviewer and either the store manager or assistant store manager completed the same questionnaire that was administered to the consumers. A total of
47 retail stores participated in the study. There were three refusals.

To compare consumers' and retailers' perceptions of actions taken in purchase transactions, a questionnaire involving fourteen scenarios depicting interactions between retailers and consumers was used. These were mainly obtained from a similar questionnaire developed by Dornoff and Tankersley (1975) as well as from complaints received by the consumer association and a hypermarket. In each scenario a purchase transaction revealing a possible cause of consumer frustration was presented and then the resulting action was stated. Respondents were requested to indicate their judgement of the actions depicted by checking a five-point Likert-type scale ranging from 'strongly agree' to 'strongly disagree'. Retailers were instructed to base their judgement on the official policy of the company regarding customer relations. The questionnaire was tested in a pilot study for suitability to measure both consumers' and retailers' perceptions. Differences between consumers' and retailers' perceptions were tested for significance using chi-square analysis.

Consumer complaints were recorded and analysed as follows: At the end of the fourteen scenarios respondents were asked an open-ended question regarding any product bought during the past year with which they might have experienced dissatisfaction. Details regarding the product's name, source of dissatisfaction, action taken, and outcome were requested.

\section{RESULTS AND DISCUSSION}

\section{Perceptions}

A comparison of consumers' and retailers' responses to the actions depicted in the scenarios is presented in Table 1 where the responses are contrasted in terms of their approval or disapproval of the scenario (indicated by 'agree' or 'disagree').

TABLE 1

CONSUMER AND RETAILER PERCEPTIONS OF PURCHASE TRANSACTIONS

\begin{tabular}{|c|c|c|c|c|c|c|c|}
\hline SITUATION & DESCRIPTION & ACTION & & JUD & $\begin{array}{l}\text { GEMENT } \\
(\%)\end{array}$ & & $\begin{array}{l}\text { SIGNIFICANCE } \\
\text { (p value)* }\end{array}$ \\
\hline \multirow[t]{3}{*}{$\begin{array}{l}\text { Short-term profit } \\
\text { maximization }\end{array}$} & \multirow{3}{*}{$\begin{array}{l}\text { A young man, recently hired as a salesman for a } \\
\text { local retail store, has been working very hard } \\
\text { to impress his boss favourably with his selling } \\
\text { ability. At times this young man, anxious for an } \\
\text { order, has been a little over-eager. To get the } \\
\text { order he exaggerates the value of the item or } \\
\text { withholds relevant information concerning the } \\
\text { product he is trying to sell. No fraud or deceit is } \\
\text { intended by his action; he is simply over eager. }\end{array}$} & \multirow{3}{*}{$\begin{array}{l}\text { His boss, the owner of the } \\
\text { retail store, is aware of this } \\
\text { salesman's actions, but has } \\
\text { done nothing to stop such } \\
\text { practice. }\end{array}$} & & Agree & No Opinion & Disagree & \\
\hline & & & $\begin{array}{l}\text { Consumers } \\
\mathrm{N}=150\end{array}$ & 11 & 2 & 87 & \\
\hline & & & $\begin{array}{l}\text { Retailers } \\
\mathrm{N}=47\end{array}$ & 11 & 4 & 85 & N.S. \\
\hline \multirow[t]{2}{*}{2.} & \multirow{2}{*}{$\begin{array}{l}\text { A local retailer has a coat with a fur collar that he } \\
\text { wants to get rid of. He has tried unsuccessfully for } \\
\text { months to sell it for R90,00. He then decides to } \\
\text { put it on sale at his approximate cost of } R 60,00 \text {. } \\
\text { He is still unable to sell the coat so he makes a new } \\
\text { price tag, listing an original price of } R 120,00\end{array}$} & \multirow{2}{*}{$\begin{array}{l}\text { The retailer marks down } \\
\text { this price }(\mathrm{R} 120,00) \text { by fifty } \\
\text { per cent to a sale price of } \\
\mathrm{R} 60,00\end{array}$} & & Agree & No Opinion & Disagree & \\
\hline & & & $\begin{array}{l}\text { Consumers } \\
\mathrm{N}=150\end{array}$ & 42 & 5 & 53 & \\
\hline
\end{tabular}

3. Repair cost A person bought a new car from a well-known dealership in the local area. Eight months after purchase, problems arose with the transmission. The car was taken back and the dealer made minor adjustments. During the next few months the same problem occurred with the transmission slipping. Each time the dealer made only minor adjustments on the car. Again during the 13th month after the car has been bought it was returned because the transmission was still not functioning properly. This time it was completely overhauled.
Since the warranty was for only one year (12 months from date of purchase) the retailer charged full price for parts and labour.

\begin{tabular}{|c|c|c|c|}
\hline & Agree & No Opinion & Disagree \\
\hline $\begin{array}{l}\text { Consumers } \\
\mathrm{N}=150\end{array}$ & 5 & 2 & 93 \\
\hline $\begin{array}{l}\text { Retailers } \\
\mathrm{N}=47\end{array}$ & 6 & 0 & 94 \\
\hline
\end{tabular}




\section{TABLE 1 (CONTINUED) \\ CONSUMER AND RETAILER PERCEPTIONS OF PURCHASE TRANSACTIONS}

\begin{tabular}{ll}
\hline $\begin{array}{l}\text { 4. After-sales } \\
\text { service }\end{array}$ & $\begin{array}{l}\text { A woman purchased a dress from a local retail } \\
\text { store. Washing instructions were attached at the } \\
\text { time of the sale and the customer was fully aware } \\
\text { of them. After wearing the dress once she washed } \\
\text { it carefully following the manufacturer's } \\
\text { instructions. Much to her dismay the colours in } \\
\text { the dress faded. It also ran and made streaks. } \\
\text { She returned to the retail store within three days } \\
\text { after purchase with the dress. }\end{array}$ \\
\hline $\begin{array}{l}\text { Misleading } \\
\text { Advertising }\end{array}$ & $\begin{array}{l}\text { A retail store ran an advertisement in the Sunday } \\
\text { newspaper announcing a sale on a well-known } \\
\text { brand of high-quality men's slacks. The } \\
\text { advertisement read that a large quantity of these } \\
\text { slacks was available. Response to the } \\
\text { advertisement was very enthusiastic. After the } \\
\text { second day of the sale, only th of the advertised } \\
\text { merchandise was still available. }\end{array}$ \\
\hline $\begin{array}{l}\text { Pre-purchase } \\
\text { information }\end{array}$ & $\begin{array}{l}\text { Sets of a well-known brand of china dinnerware } \\
\text { are advertised on sale at a considerable discount } \\
\text { by a retailer. Several patterns of a typical } \\
\text { 45-piece service for eight are listed. The customer } \\
\text { may also buy any odd pieces which are available } \\
\text { in stock (butter dish, gravy bowl, etc.). The } \\
\text { advertisement does not indicate, however, that } \\
\text { these patterns have been discontinued by the } \\
\text { manufacturer. }\end{array}$ \\
\hline 7. Pricing policy & $\begin{array}{l}\text { A retail grocery chain operates several stores } \\
\text { throughout the local area including one in the } \\
\text { city's poor area. Independent studies have shown } \\
\text { that prices do tend to be higher and there is less of } \\
\text { a selection of products in this particular store } \\
\text { than in other locations. }\end{array}$ \\
\hline
\end{tabular}
8. Promotion
policy
Some research showed that consumers are misusing product $\mathrm{X}$, a product distributed and sold through local retailers. There is no danger involved in this misuse; the consumers are simply waisting money by using too much. Displays, which actually seem to encourage this misuse, are provided by the manufacturer. A certain retailer is aware that consumers are misusing product $\mathrm{X}$. $\mathrm{He}$ is also aware that the manufacturer's display encourages this misuse.
The retailer refused to refund her money since the dress had been worn and washed.

(

\begin{tabular}{|c|c|c|c|}
\hline & Agree & No Opinion & Disagree \\
\hline $\begin{array}{l}\text { Consumers } \\
\mathrm{N}=150\end{array}$ & 1 & 1 & 98 \\
\hline $\begin{array}{l}\text { Retailers } \\
\mathrm{N}=47\end{array}$ & 6 & 3 & 91 \\
\hline
\end{tabular}

The retailer continued to run the advertisement each day for an entire week up to and including the following Saturday.

\begin{tabular}{|c|c|c|c|}
\hline & Agree & No Opinion & Disagree \\
\hline $\begin{array}{l}\text { Consumers } \\
\mathrm{N}=150\end{array}$ & 23 & 6 & 71 \\
\hline $\begin{array}{l}\text { Retailers } \\
\mathrm{N}=47\end{array}$ & 19 & 9 & 72 \\
\hline
\end{tabular}

The retailer offers this information only if the customer directly asks if the merchandise is discounted.

\begin{tabular}{|c|c|c|c|}
\hline & Agree & No Opinion & Disagree \\
\hline $\begin{array}{l}\text { Consumers } \\
\mathrm{N}=150\end{array}$ & 43 & 8 & 49 \\
\hline $\begin{array}{l}\text { Retailers } \\
\mathrm{N}=47\end{array}$ & 40 & 17 & 43 \\
\hline
\end{tabular}

On the day welfare cheques are received in the area of the city the retailer

increases prices on all his merchandise.

\begin{tabular}{|c|c|c|c|}
\hline & Agree & No Opinion & Disagree \\
\hline $\begin{array}{l}\text { Consumers } \\
\mathrm{N}=150\end{array}$ & 2 & 2 & 96 \\
\hline $\begin{array}{l}\text { Retailers } \\
\mathrm{N}=47\end{array}$ & 0 & 9 & 91 \\
\hline
\end{tabular}

The retailer continues to use this display in his store. Agree No Opinion Disagree

\begin{tabular}{llll}
\cline { 2 - 4 } Consumers & 14 & 13 & 73 \\
$\mathrm{~N}=150$ & & & \\
Retailers & 21 & 17 & 62 \\
$\mathrm{~N}=47$ & & &
\end{tabular}

On the account sent by the retailer interest charges were included since the

According to a store's credit policy any purchase made before the 10th of the month is included on the account. Full payment is required on an account within 25 days of this day (usually the 5 th of the following month). If not paid in full, interest charges are added to the balance. A person ordered a furniture piece from this store on May 9 th and charged the purchase to his credit account had not been paid by the due date, June 5 .

\begin{tabular}{|c|c|c|c|}
\hline & Agree & No Opinion & Disagree \\
\hline $\begin{array}{l}\text { Consumers } \\
\mathrm{N}=150\end{array}$ & 4 & 4 & 92 \\
\hline Retailers & 11 & 6 & 83 \\
\hline
\end{tabular}
account. The particular piece of furniture was not available for immediate delivery. By June 5 the furniture had still not been delivered, so the bill was not paid. The furniture finally arrived on June 7 and a cheque was then sent to the store for payment in full. The June 10 account was received the following week.

\footnotetext{
10. Gift exchange A customer brings a coffee pot into the store which he explains was a wedding gift. He indicates that he already has a fine coffee pot and would like a cash refund. The pot is carried by the store, but since it was a gift the man has no sales slip. The pot retails at $R 12,00$
} The man should receive a
full cash refund.

\begin{tabular}{|c|c|c|c|}
\hline & Agree & No Opinion & Disagree \\
\hline $\begin{array}{l}\text { Consumers } \\
\mathrm{N}=150\end{array}$ & 48 & 10 & 42 \\
\hline $\begin{array}{l}\text { Retailers } \\
\mathrm{N}=47\end{array}$ & 47 & 11 & 42 \\
\hline
\end{tabular}

11. Price reduction A customer purchased a bicycle from a store at a The store should refund cost of R60,00. A week later the same bicycle is the customer the difference. put on sale by that store for R49,00.

Agree No Opinion Disagree

\begin{tabular}{llll} 
& & & \\
\cline { 2 - 4 } Consumers & 9 & 2 & 89 \\
$\mathrm{~N}=150$ & & & \\
$\begin{array}{l}\text { Retailers } \\
\mathrm{N}=47\end{array}$ & 2 & 4 & 94
\end{tabular}

N.S. 


\section{TABLE 1 (CONTINUED) CONSUMER AND RETAILER PERCEPTIONS OF PURCHASE TRANSACTIONS}

\begin{tabular}{|c|c|c|c|c|c|c|c|}
\hline \multirow[t]{3}{*}{$\begin{array}{l}\text { 12. Obsolete } \\
\text { merchandise }\end{array}$} & \multirow{3}{*}{$\begin{array}{l}\text { A customer purchased a foundation garment. A } \\
\text { year later the garment was returned with no sales } \\
\text { slip. Since that time, styles had changed and the } \\
\text { garment had been reduced to half price. The } \\
\text { customer requested a full cash refund. }\end{array}$} & \multirow{3}{*}{$\begin{array}{l}\text { The customer should not } \\
\text { receive the full refund } \\
\text { but should receive the } \\
\text { current selling price. }\end{array}$} & \multirow{3}{*}{$\begin{array}{l}\text { Consumers } \\
\mathrm{N}=150 \\
\text { Retailers } \\
\mathrm{N}=47\end{array}$} & Agree & No Opinion & Disagree & \multirow[b]{3}{*}{ N.S. } \\
\hline & & & & 47 & 10 & 43 & \\
\hline & & & & 59 & 9 & 32 & \\
\hline \multirow[t]{3}{*}{$\begin{array}{l}\text { 13. After/sales } \\
\text { repair cost }\end{array}$} & \multirow[t]{3}{*}{$\begin{array}{l}\text { A customer calls the retailer to report that her } \\
\text { refrigerator purchased two weeks earlier is not } \\
\text { cooling properly and that all the food has spoiled. }\end{array}$} & \multirow[t]{3}{*}{$\begin{array}{l}\text { The retailer should repair } \\
\text { the refrigerator at no cost. }\end{array}$} & & Agree & No Opinion & Disagree & \\
\hline & & & $\begin{array}{l}\text { Consumers } \\
\mathrm{N}=150\end{array}$ & 93 & 4 & 3 & \\
\hline & & & $\begin{array}{l}\text { Retailers } \\
\mathrm{N}=47\end{array}$ & 96 & 0 & 4 & N.S. \\
\hline \multirow[t]{3}{*}{$\begin{array}{l}\text { 14. Damage due to } \\
\text { malfunctioning } \\
\text { product }\end{array}$} & \multirow[t]{3}{*}{$\begin{array}{l}\text { A customer calls the retailer to report that her } \\
\text { refrigerator purchased two weeks earlier is not } \\
\text { cooling properly and that all the food has spoiled. }\end{array}$} & \multirow[t]{3}{*}{$\begin{array}{l}\text { The customer should be } \\
\text { re-imbursed for the value } \\
\text { of the spoiled food. }\end{array}$} & & Agree & No Opinion & Disagree & \\
\hline & & & $\begin{array}{l}\text { Consumers } \\
\mathrm{N}=150\end{array}$ & 56 & 8 & 36 & \\
\hline & & & $\begin{array}{l}\text { Retailers } \\
\mathrm{N}=47\end{array}$ & 40 & 15 & 45 & N.S. \\
\hline
\end{tabular}

Responses of consumers and retailers were significantly different in five of the fourteen transactional situations. These situations relate mainly to the post-purchase phase. Situations of potential frustration for consumers and retailers were identified in after-sales service, financing of repair cost, credit benefits, misleading advertising, and damage caused by a malfunctioning product. The results obtained in the remaining nine situations do not support the hypothesis that the perceptions of retailers and consumers towards actions taken in frustrating situations are different.

Although the overall outcome of the results of the study is inconclusive, it is encouraging to note that the general trend observed demonstrates perceptual harmony and understanding between consumers and retailers regarding their needs and priorities. We cannot conclude that retailers opted for a more profitable cause of action in all the situations portrayed. On the contrary, we speculate that in many instances retailers completing the questionnaire identified strongly with the consumers' role and responded likewise. This occurred despite clear instructions to convey the companies' policy in each situation portrayed. A close inspection of the results portrayed for each situation in Table 1 reveals that in many instances the largest proportion of both consumers and retailers disagreed with the actions taken. This implies that both parties are sensitive to situations which may hamper good relationships.

\section{Complaints}

Tables 2 and 3 display data obtained from 60 respondents who had indicated dissatisfaction with a recently-bought product. Although these tables are self-explanatory it is interesting to note from table 2 that a substantial number of complaints were received from middle-aged females in the middle to upper income and residential areas of Port Elizabeth.

TABLE 2

DEMOGRAPHIC CHARACTERISTICS OF COMPLAINTANTS

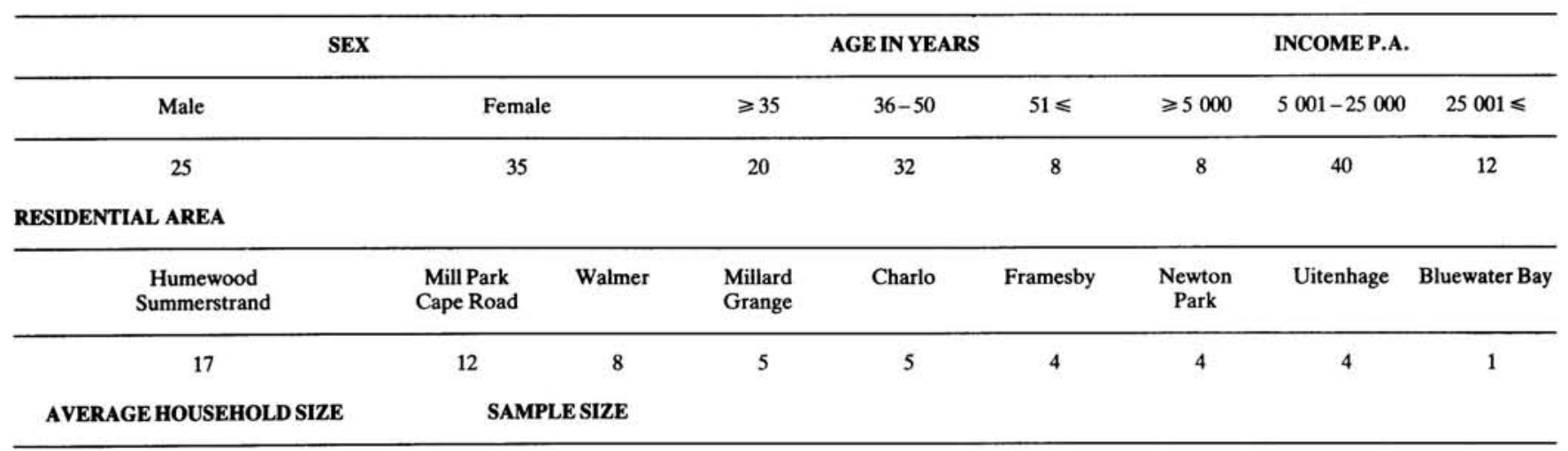


TABLE 3

\section{SURVEY COMPLAINTS}

\begin{tabular}{|c|c|c|c|c|c|c|}
\hline PRODUCT CATEGORY (\%) & & & & & & \\
\hline $\begin{array}{l}\text { Household appliances \& } \\
\text { audio/visual equipment }\end{array}$ & $\begin{array}{l}\text { Clothing \& } \\
\text { Jewellery }\end{array}$ & $\begin{array}{c}\text { Food } \\
\text { products }\end{array}$ & Furniture & $\begin{array}{l}\text { Motor vehicles } \\
\text { accessories \& parts }\end{array}$ & $\begin{array}{c}\text { Books \& } \\
\text { Magazines }\end{array}$ & Service Contracts \\
\hline 38 & 15 & 14 & 13 & 10 & 5 & 5 \\
\hline
\end{tabular}

\begin{tabular}{|c|c|c|c|c|}
\hline Defects, Malfunctioning & After-Sales Service & Perishables gone off & Price quality & Advertising \& sales gimmicks \\
\hline 35 & 32 & 28 & 3 & 2 \\
\hline
\end{tabular}

\begin{tabular}{ccc}
\hline Complained & Switched brands & Negative word-of-mouth \\
\hline 87 & 8 & 5 \\
OUTCOME (\%) & & \\
\hline
\end{tabular}

\begin{tabular}{|c|c|c|}
\hline Satisfied ${ }^{*}$ & Dissatisfied ** & \\
\hline 90 & 10 & $\begin{array}{ll}\text { - } & \mathrm{N}=60 \\
\text { *. } & \text { Product replaced, person refunded } \\
& \text { Still waiting for reply, refused } \\
\text { to assist, replace, return. }\end{array}$ \\
\hline
\end{tabular}

Table 3 shows an analysis of complaints received. Five main product categories causing dissatisfaction emerged, namely, household appliances, clothing, food products, furniture, and motor vehicles. Apart from defects and malfunctioning, poor after-sales service and perishable food items were the main sources of dissatisfaction. Of these respondents who lodged complaints, the largest percentages were satisfied with the outcome of the action taken. Those results support those obtained in an earlier study by the South African Co-ordinating Consumer Council (Weyers, 1985).

The results of this study have important implications for retailers and consumers. Both parties should be more sensitive to one another's perceptions of priorities and legitimate rights in market transactions. Such awareness would eliminate misunderstandings and post-purchase frustrations. Complaints should be taking preventative action. Consumers may be educated to shop wisely (i.e. avoid impulse buying and overspending) whilst retailers may provide in-store channels to file complaints. Such action would prevent negative word-of-mouth communication, a potentially dangerous practice to the store or company image and most difficult to combat (Richins, 1983).

Limitations of the study should be mentioned here. As is common in most field studies the data obtained is subject to "report error". This implies that the way in which respondents act in questionnaires does not necessarily reflect their true feelings and behaviour. A further limitation is that the results are based on a relatively small sample representing a single metropolitan area.

Respondents from rural areas and other racial groups were excluded owing to political disturbances. Owing to uneven representation of retailer types in the sample no attempt was made to test for significant differences in perception between consumers and each type of retailer. The results might not have been the same as for retailers in general. Despite these limitations, tentative conclusions may be drawn.

\section{CONCLUSION}

This study has demonstrated that differences do exist between what consumers and retailers feel are appropriate actions to be taken in the post-purchase phase. Rather than being complacent about the consensus identified in the study, retailers and consumers should strive towards improved business relationships by focussing on those areas where perceptual disharmony still prevails. With careful analysis and prompt replies, the incidence of consumer complaints could be turned into positive experiences for both parties.

\section{REFERENCES}

Andreason, A.R. (1984). Life status changes and changes in consumer preferences and satisfaction. Journal of Consumer Research, 11, 784-794.

Andreason, A.R. (1985). Consumer responses to dissatisfaction in loose monopolies. Journal of Consumer Research, 12, 135-141.

Day, G.S. (1982). Are consumers satisfied? In Aaker, D.A. \& Day, G.S. (Eds.) Consumerism Search for the Consumers' Interest (4th ed.) 403-415. New York: Free Press.

Dornoff, R.I. \& Tankersley, C.B. (1982). Perceptual differences in market transactions. In Aaker, D.A. \& Day, G.S. (Eds.). Consumerism Search for the Consumers' Interest. (4th ed.) 426-433. New York: Free Press.

Hill, R. (1982). Dealing with consumer complaints. International Management, 1, 17-19.

Resnik, A.J. \& Harmon, R.R. (1983). Consumer complaints and managerial response. A holistic approach. Journal of Marketing, 47, 86-97.

Richins, M.L. (1983). Negative word-of-mouth by dissatisfied consumers. A pilot study. Journal of Marketing, 47, 68-78.

Rousseau, G. (1985). Prepurchase information search and postpurchase consumer processes. Proceedings of the Third National Psychology Conference. Pretoria: Department of Psychology, University of Pretoria.

Rousseau, D. (1986). Customers' Criteria. Marketing Mix, 4, 44.

Weyers, J.L. (1985). Complaints. Consumer Council Annual reports 1981-1982, 1984-1985, Pretoria. 